\title{
Problematika Masyarakat Lokal Dalam Pengembangan Desa Wisata Bayung Gede, Kecamatan Kintamani, Kabupaten Bangli
}

I Made Pujiwiyasnawa a, 1, I Gusti Agung Oka Mahagangga a, 2

1 pande.pujiwiyasnawa@yahoo.com. ${ }^{2}$ okamahagangga@unud.ac.id

a Program Studi Sarjana Destinasi Pariwisata, Fakultas Pariwisata,Universitas Udayana, Jl. Dr. R. Goris, Denpasar, Bali 80232 Indonesia

\section{Abstract}

This research aims to find out the problems of local community of Bayung Gede to develop tourism Village. Research technique as qualitative method to find, describe and understanding focus of this research. With purpossive sampling as the specific informant and technique analysis data used descriptive qualitative.

The result of this research show a complex problems when local community of Bayung Gede develop their own tourism village. The problems are garbage, infrastructure maintenance, vision and mission tourism village equalizing, souvenir core product and marketing icons. However, as long few years this tourism village has been succeed to done tourism activity with not forced participation or spontal typical participate.

\section{Keywords: Problems, Participation, Tourism Village,}

\section{PENDAHULUAN}

Desa Wisata Bayung Gede adalah salah satu desa wisata yang memiliki banyak keunikan. Terdapat tradisi-tradisi yang memiliki perbedaan dengan desa lain di Bali. Seperti ari-ari bayi yang baru lahir, kuburan (setra) ari-ari, sistem saih nembelas, dan masih banyak tradisi unik lainnya.

Sejak ditetapkannya sebagai pilot project pariwisata tahun 2010 tertuang dalam SK Kementerian Koordinasi Bidang Kesara Nomor $\quad 10.13 .834 / K M D / D / V I I / V / 2010$, diputuskan membangun desa Bayung Gede berbasis pariwisata budaya. Sebagai proyek percontohan desa Bayung Gede memperoleh bantuan dana pemerinth pusat sebesar Rp. 2,5 milyar dari Program Nasional Pemberdayaan Masyarakat Mandiri (PNPM).

Permasalahannya adalah sampai penelitian ini dilakukan terdapat asumsi desa Bayung Gede memiliki beberapa problematika dalam pengembangan desa wisata. Asumsi ini menjadi fokus penelitian termasuk solusiuntuk pengembangan desa wisata Bayung Gede dan keberlanjutannya di masa depan.

\section{KEPUSTAKAAN}

Penelitian menggunakan bebera konsep dan teori sebagai alat melakukan analisis. Ada pun konsep dan teori yang digunakan adalah partisipasi masyarakat (Tosun, 2006), Desa Wisata (Nuryanti, (1993), dalam Suryasih, dkk., 2016) dan problematika yaitu permasalahanpermasalahan yang dihadapi dan merupakan akumulasi dari berbagai faktor (Anom, dkk., 2016).

\section{METODE PENELITIAN}

Penelitian menggunakan metode kualitatif (Moleong, 2005), dengan teknik penentuan informan menggunakan purposive sampling (Gunawan, 2013), teknik pengumpulan data yaitu observasi dan wawancara (Bungin, 2003), dan teknik analisis data kualitatif (Sugiyono, 2004).

\section{HASIL DAN PEMBAHASAN \\ 4.1 Sekilas desa Bayung Gede}

Desa Bayung Gede adalah suatu desa yang terletak di Kecamatan Kintamani, Kabupaten Bangli. Desa ini terletak sekitar 55 km timur laut Denpasar, serta sekitar $35 \mathrm{~km}$ ke arah utara Kota Bangli.

Pada umumnya warga desa Bayung Gede merupakan petani penggarap. Banyak warga desa yang tidak memiliki lahan mereka sendiri. Hanya sebatas sebagai penyakap (menggarap lahan milik orang lain). Hasil pertanian yang berkembang cukup baik, tidak berbeda jauh dengan desa-desa lainya di dataran Kintamani. Adapaun hasil pertanian meliputi jeruk, kopi aneka jenis sayuran, jagung serta padi gaga. Komoditi favorit tentu saja jeruk Kintamani, diikuti pengembangan jeruk Siam.

Sejak dahulu desa Bayung Gede memiliki daya tarik bagi masyarakat lain di Bali dan bahkan sampai ke luar negeri. Bahkan pada tahun 1930-an sudah masuk para peneliti asing melakukan penelitian di Desa Bayung Gede 
seperti antropolog Mead dan Psikolog Bateson (Anom, dkk., 2016).

\subsection{Problematika Masyarakat Lokal dalam Pariwisata}

Pariwisata mulai dilirik oleh masyarakat desa Bayung Gede ketika disadari bahwa keunikan budaya dan alam merupakan komponen penting dalam pelestarian maupun pembangunan ekonomi. Diawali dari aktifitas perorangan, diikuti oleh beberapa individu lin sampai terbentuknya Kelompok Sadar Wisata (Pokdarwis) memiliki proses panjang.

Adapun aktivitas yang dilakukan oleh masyarakat desa Bayung Gede dalam pengembangan pariwisata yaitu penataan hutan bambu, pengembangan agrowisata (perkebunan jeruk, kopi, jagung, markisa, terong belanda, dan jenis holtikultura lainnya, di buka restoran buah organik), penataan fasiltas (toilet umum, trotoar jalan, perbaikan akses menuju ke setra atau kuburan ari-ari, sarana parkir wisatawan, loket tiket untuk wisatawan, tong sampah, homestay, Pusat Informasi Wisatawan / TIC).

Hasil penelitian menunjukkan partisipasi masyarakat lokal desa Bayung Gede dalam pengembangan desa wisata relatif baik. Secara teoritis tipe partisipasinya bersifat spontan (Tosun, 2006). Tampak dari aktivitas yang dilakukan oleh masyarakat dilakukan tanpa intervensi.

Tetapi jika dilakukan analisis secara lebih mendalam terdapat beberapa problematika dalam pengembangan desa wisata di Desa Bayung Gede. Problematika tersebut antara lain :
a. Sampah
b. Perawatan infrastruktur
c. Penyamaan Visi dan misi Desa Wisata
d. Belum memiliki ikon souvenir
e. Pemasaran

Keempat problematika di atas belum sepenuhnya disadari oleh masyarakat lokal. Kebanyakan menganggap problematikaproblematika tersebut di atas justru bukan permasalahan. Hal ini kemungkinan disebabkan karena sampai saat ini hasil dari kedatangan wisatawan dan hasil dari perkebunan masih mampu menopang pendapatan atau perekonomian warga setempat.

Padahal problematika-problematika tersebut di atas dapat menjadi hambatan di masa mendatang. Keberlanjutan pembangunan sektor pariwisata sering sebatas wacana, namun ketika menemui permasalahan seperti menurunnya jumlah kunjungan wisatawan, dan kerusakan lingkungan, baru disadari bahwa sangat penting memperhatikan aspek sosialbudaya, aspek lingkungan selain aspek ekonomi sebagai yang utama dalam pembangunan pariwisata.

Kelima problematika pengembangan desa wisata Bayung Gede yaitu sampah, perawatan infrastruktur, penyamaan visi dan misi desa wisata, belum memiliki ikon souvenir dan pemasaran terjadi, karena Pertama, masyarakat lokal masih bertumpu kepada spontanitas yang tidak lepas dari nilai-nilai budaya lokal yang mentradisi. Artinya, masyarakat lokal sudah memandang penting pariwisata namun seandainya tanpa pariwisata kehidupan tradisi, adat-istiadat, agama dan sosial kemasyarakatan akan tetap berjalan. Perlindungan dari Tuhan dan para leluhur, ketika sudah menjalankan kewajiban-kewajiban akan menjadi tameng (perlindungan) dalam kehidupan keseharian.

Kedua, seperti hampir seluruh desa di Bali dan mungkin di Indonesia, peran tokoh masyarakat sangat penting. Kepeloporan tokohtokoh masyarakat mulai dari kepala desa, Bendesa Adat dan Ketua Pokdarwis maupun komponen masyarakat yang telah berhasil dalam bidang pariwisata (termasuk perkebunan) secara langsung dipercaya dan menjadi panutan. Sehingga berbeda dengan masyarakat desa di negara-negara maju, spontanitas dapat hadir sebagai implikasi dari status-status sosial di masyarakat.

Berdasarkan temuan problematika pengembangan desa wisata di desa Bayung Gede maka dapat diupayakan langkah-langkah sebagai berikut :

1. Pelaksanaan Sapta Pesona yang digerakkan oleh Pokdarwis dan mengadopsi sistem pengelolaan sampah moderen

2. Membentuk Badan Usaha Milik Desa (Bumdes atau Koperasi) yang secara professional berorientasi profit untuk perawatan fisik infrastruktur termasuk pelestarian budaya

3. Ketokohan adalah hal penting di desa Bayung Gede, dan akan menjadi semakin kuat jika visi dan 
misi desa wisata mampu dilaksanakan bersama

4. Melalui Bumdes dan sejenisnya dibuka sanggar seni dan art shop sesuai dengan potensi alam-budaya lokal

5. Aspek pemasaran dikelola terintegrasi, difasilitasi oleh Dinas Pariwisata Kabupaten Bangli dan kerjasama dengan travel agent (core product dan target pasar).

Langkah-langkah di atas masih bersifat makro dan diperlukan penjabaran secara lebih spesifik. Dapat dilakukan melalui aspek perencanaan meliputi kajian akademis pengembangan desa wisata Bayung Gede, dilanjutkan dengan penyusunan masterplan, siteplan dan actionplan.

\section{PENUTUP}

\subsection{Simpulan}

Tipologi partisipasi masyarakat lokal di desa Bayung Gede adalah partisipasi spontan, namun kesukarelaan tersebut terjadi karena peran ketokohan yang kuat, dipayungi oleh tradisi, adat-istiadat dan budaya Bali Kuno yang unik bercampur dengan kehidupan moderen yang menyatu dalam keseharian masyarakat. Hal ini melahirkan problematika pengembangan desa wisata Bayung Gede seperti pengelolaan sampah, perawatan infrastruktur, sinkronisasi visi dan misi desa wisata, belum memiliki ikon souvenir dan pemasaran.

\subsection{Saran}

Ada pun saran-saran yang dapat disampaikan berdasarkan hasil penelitian sebagai berikut :

1. Pemerintah kabupaten dalam hal ini Dinas Pariwisata Bangli harus memahami problematika desa Bayung Gede dalam pengembangan desa wisata utnuk menyusun program-program kerja dalam penyelesaiannya

2. Tokoh-tokoh masyarakat desa Bayung Gede harus mampu menjadi suritauladan dan semakin meningkatkan pengetahuan tentang pariwisata. Termasuk upaya pengembangan pariwisata secara sinergis untuk pelestarian budaya dan alam.
3. Perlu dilakukan perencanaan pariwisata secara holistik dan integral keyika persaingan daya tarik wisata di Bali semakin kompetitif.

\section{DAFTAR PUSTAKA}

Anonim. 2010. Surat Keputusan Koordinasi Bidang Kesra Nomor 10.13.834/KMD/D/VII/V/2010 : Desa Bayung Gede Berbasis Pariwiata Budaya. Jakarta : Kemenkokesra RI

Anom, I Putu. Nugroho, Saptono. Mahagangga, I Gusti Agung. 2016. "Problematika Pariwisata Bali, Membangun Paradigma Pariwisata di Masa Depan". Penelitian yang Tidak Dipublikasikan, Laporan Penelitian Hibah Unggulan Udayana. Bukit jimbaran : LPPM Universitas Udayana

Anom, I Putu. Suryasih, Ida Ayu. Nugroho, Saptono. Mahagangga, I Gusti Agung. 2017. Turismemorfosis : Seratus Tahun Perkembangan Pariwisata Bali. Jurnal Kajian Bali . ISSN 20884443. Volume 07, Nomor 02. Oktober 2017. Denpasar : Universitas Udayana

Bungin, Burham. 2007. Penelitian Kualitatif : Komunikasi, Ekonomi, Kebijakan publik, dan Ilmu Sosial l ainnya. Kota: Prenada Media Group

Gunawan, Imam. 2013. Metode Penelitian Kualitatif : Teori dan Praktik. Jakarta. Bumi Aksara.

Moleong,Lexy J. 2005. Metodelogi Penelitian Kualitatif.Bandung : Remaja Rosda Karya.

Sugiyono. 2008. Memahami Penelitian Kualitatif. Bandung : Alfa Deta.

Suryasih, Ida Ayu. Suryawan, Ida Bagus.. Anom, I Putu (Ed). 2016. Perkembangan dan Pengembangan Desa Wisata di Kabupaten Badung. Bogor : Herya Media

Tosun, Cevat. 2000. "Limits to Cummunity Parcipation in the Tourism Development Process in Developing Countries". Tourism Management, 21, pp.613-633. 